\title{
Effect of Calf Crop on Net Income of a Nev- ada Range Cattle Operation
}

\author{
L.A. TORELL, C.F. SPETH, AND C.T.K. CHING
}

\begin{abstract}
This paper examines the effects of calf crop percentages on net income. Calf crop is defined as the ratio of the number of calves born to the number of mature cows and first-calf heifers. Net income is gross cattle sales less operating costs. The results show that high calf crops are not necessarily the most feasible in an economic sense. Rather, ranchers should consider the added costs of achieving a higher calf crop percentage and compare them to the associated added sales. The higher level calf crop is economically feasible only if added sales are greater than or equal to added costs.

A major problem with Western range cattle operations is low reproductive performance or calf crop - ratio of the number of calves born to the number of mature cows and first-calf heifers. In this definition of calf crop, it is assumed that culled cows have been exactly replaced by breeding age heifers. This definition is consistent with the way calf crop is normally reported on ranches. Generally, ranchers view total number of calves born relative to the average herd size. Herd size is normally thought of in terms of number of mature cows. In a stable situation, a certain percent of mature cows are culled and replaced by heifers. The equations of the model described below are formulated to account for exact replacement of culled cows. Following this definition, calf crop in Northeastern Nevada is generally accepted as being about $70 \%$. Rogers and Helming (1967) and Mitchell and Garrett (1977) both report calf crop percentages of this approximate magnitude.

Many factors can influence calf crop such as management practices, condition of the breeding herd, stocking rates, and nutrition. Several of these factors such as condition of the breeding herd and stocking rates are closely related to variations in nutrition. Unfortunately, all factors and their degree of influence on calf crop are not generally known. A notable exception is the nutritional influence on calf crop reported by Wiltbank and others $(1962,1964)$ in mature cows and by Dunn and others (1969) in 2-year old heifers.

Given the paucity of basic data on factors influencing calf crop and the relative availability of nutritional influences, this study focuses upon the economic effect of various calf crop percentages as influenced by nutritional level. Effect in this instance is measured by net income of a typical Northeastern Nevada cow yearling operation. Net income as used in this paper is defined as gross sales minus the cost of operating the ranch.
\end{abstract}

\section{Procedure}

Linear programming (LP) is used to estimate the effect of various levels of calf crop on net revenue. Beneke and Winterboer (1973) describe the LP technique. In addition, the technique is often used by range management researchers. See, for example, Woodworth (1973), D’Aquino (1974), Bartlett et al. (1974), Leistritz and Qualey (1975), Bottoms and Bartlett (1975), and Hewlett

Authors are economist, Resource Concepts, Inc., Carson City, Nev; associate professor, Animal Science Division, University of Nevada, Reno; and professor, Department of Agricultural and Resource Economics, University of Hawaii.

This research is a contribution from the Agr. Exp. Sta., University of Nevada, Reno, Journal Series Number 509.

Manuscript received December 20, 1980. and Workman (1978).

The specific LP model developed by Ching and others (1977) describes the resources and activities of a typical Elko County, Nev., ranch. The resources and activities of the model ranch are described in Tables 1 and 2. This particular LP model incorporates linear equations to depict the seasonal flow of herbage quantity and quality throughout the production year. Seasonal total digestible nutrients (TDN) requirements for the various livestock classes are considered explicitly.

Table 1. Resource levels of medium size ranch, northeastern Nevada.

\begin{tabular}{lr}
\hline Resource & \multicolumn{1}{c}{ Level } \\
\hline Alfalfa hay land & 78 Acres \\
Grass hay land & 250 Acres \\
Irrigated pasture land & 1,035 AUMS \\
Deeded range land & 123 AUMS \\
BLM range land & 1,500 AUMS \\
FS range land & 900 AUMS \\
\hline
\end{tabular}

In this application, linear programming is used to allocate resources (e.g., alfalfa hay lands, grass hay lands, and various classes of grazing lands) among various activities (e.g.. feeding various classes of cattle) to maximize the objective function of net income. In mathematical notation, the linear programming model is stated as:

$$
\begin{gathered}
\text { Mubject to } \underset{\mathrm{i}=1}{\operatorname{Maximize}} R=\sum_{\mathrm{j}=1}^{\mathrm{n}} c_{\mathrm{j}} x_{\mathrm{j}} \\
x_{\mathrm{j} \geq 0, \mathrm{j}} \geq 01,2, \ldots, n
\end{gathered}
$$

where,

$$
\begin{aligned}
& R=\text { net income } \\
& c_{\mathrm{j}}=\text { cost or return associated with an activity, } x_{\mathrm{j}} \\
& x_{\mathrm{j}}=\text { level of activity } \mathrm{j} \\
& b_{\mathrm{i}}=\text { amount of resource } \mathrm{i} \text { available } \\
& a_{\mathrm{ij}}=\text { amount of resource } \mathrm{i} \text { required to produce one unit of } \\
& \text { activity, } x_{\mathrm{j}} \\
& n=\text { number of activities } \\
& m=\text { number of constraints }
\end{aligned}
$$

Research presented by Wiltbank and others (1962) was utilized to determine the effect of various calf crops, as influenced by the level of nutrition, on the net income of a typical Nevada cowyearling operation (Table 3). Consider, for example, the feeding regimen corresponding to a high-low energy level. In such a situation each cow must receive no less than $4.1 \mathrm{~kg}$ of TDN/day before calving and no less than $3.6 \mathrm{~kg}$ of TDN/day after calving to yield a $77 \%$ calf crop. Equations describing these relationships make up a part of restrictions or constraints in the LP model. Similar equations were formulated for the other TDN levels (high-high, lowhigh, and low-low). LP model results show the maximum net income obtainable from the four combinations of energy intake 
Table 2. Description and costs (prices) associated with the cost and returns activities for the model ranch.

\begin{tabular}{|c|c|c|}
\hline Cost activities & Activity description & Cost/ unit ${ }^{1}(\$)$ \\
\hline Alfalfa hay production & Growing and harvesting 1 hectare of alfalfa hay & $234.50 /$ ha \\
\hline Grass hay production & Growing and harvesting 1 hectare of grass hay & $54.00 /$ ha \\
\hline Irrigated pasture grazing & Use of 1 AUM of irrigated pasture land & 13.50/AUM \\
\hline Deeded range grazing & Use of 1 AUM of owned private range & $3.50 / \mathrm{AUM}$ \\
\hline BLM grazing & $\begin{array}{l}\text { Use of } 1 \text { AUM of BLM range for grazing (includes the grazing } \\
\text { fee) }\end{array}$ & $6.54 / \mathrm{AUM}$ \\
\hline FS grazing & $\begin{array}{l}\text { Use of } 1 \text { AUM of Forest Service range for grazing (includes } \\
\text { the grazing fee) }\end{array}$ & $6.60 / \mathrm{AUM}$ \\
\hline Aftermath & Aftermath grazing & $.00 \mathrm{AUM}^{2}$ \\
\hline Buy alfaifa & Purchase of $1 \mathrm{~kg}$ of alfalfa hay & $.077 / \mathrm{kg}$ \\
\hline Buy grass hay & Purchase of $1 \mathrm{~kg}$ of grass hay & $.066 / \mathrm{kg}$ \\
\hline Buy protein supplement & Purchase of $1 \mathrm{~kg}$ of protein supplement & $.143 / \mathrm{kg}$ \\
\hline Raise cow & Raising a cow for breeding purposes & $8.00 /$ cow $^{3}$ \\
\hline Raise yearling & Raising a yearling for sale & $.00 /$ head $^{4}$ \\
\hline Raise bull & Raising a bull for breeding purposes & $.00 /$ head $^{4}$ \\
\hline Return activities & Activity description & Price $/ \mathrm{kg}^{5}(\$)$ \\
\hline Sell cows & The gross income from selling $1 \mathrm{~kg}$ of cull cows & $.54 / \mathrm{kg}$ \\
\hline Sell bulls & The gross income from selling $1 \mathrm{~kg}$ of cull bull & $.75 / \mathrm{kg}$ \\
\hline Sell yearlings & The gross income from selling $1 \mathrm{~kg}$ of yearling production & $1.06 / \mathrm{kg}$ \\
\hline
\end{tabular}

These figures represent per unit operating cost to a Nevada rancher for 1978 .

${ }^{2}$ No cost was associated with this activity since it is primarily a residual product of hay production.

${ }^{3}$ Includes miscellaneous expenses of raising a cow such as veterinary expenses, cattle handling, etc.

${ }^{4}$ No cost was charged to this activity. The cost of raising a cow $(\$ 8.00 /$ cow) includes veterinary expenses, cattle handling, etc., for all livestock classes.

${ }^{5}$ These figures represent per unit returns to the rancher at the average price received during the first 6 months of 1978 in Nevada, (USDA, 1978).

and calf crop. Consistent with the studies by Wiltbank and others $(1962,1964)$, only the influence of energy levels on calf crop was considered. No attempt is made to include other nutritional dimensions.

The source of production and cost parameters utilized in the linear programming model was a survey conducted by Mitchell and others (1977) to identify the characteristics of the range cattle industry in Northeastern Nevada for 1972 . The prices paid by farmers index (USDA, 1978) was utilized to adjust cost activities to the 1978 price level wherc applicable. A brief description of the major activities and their associated per-unit cost or return are listed in Table 2.

It should be re-emphasized that there is limited data available on factors influencing calf crop. And, nutritional data and their influence on calf crop were the only data that the authors were able to find to use in the study. Accordingly, it is critical that the data used is consistent with the range operation studied in this analysis.

Research by Wiltbank and others (1962) was conducted under feedlot conditions where each cow was fed varying amounts of alfalfa, corn, beet pulp, and soybean meal so that the desired TDN levels oefore and after calving could be achieved. The TDN level on a typical Northeastern Nevada range has been shown by Connor and others (1963) to average $61 \%$ which corresponds closely to the 63\% TDN level fed to the low post-calving energy group of cows in the experiments by Wiltbank and others (1962). The validity of the results of this study depends upon the comparability of the data by Wiltbank and others (1962) and the conditions found on Northeastern Nevada range operations. Based on TDN levels fed, the authors believe the data to be sufficiently comparable to permit analysis.

\section{Results and Discussion}

Utilizing linear programming and data from Wiltbank and others (1962) net incomes associated with alternative pre-calving and post-calving feeding rates we re estimated (Table 4). When low-low energy levels are fed, net income and calf crop are at their lowest point. If energy levels are increased in either the pre-calving or post-calving period, or both, calf crop and net income increase. Net income is at a maximum with the low-high feeding regimen.

Initially one might think that securing a maximum calf crop would be the objective of any rancher. However, a major point to
Table 3. Pregnancy rate ${ }^{1}$ for various energy levels.

\begin{tabular}{lccc}
\hline $\begin{array}{l}\text { Pre-calving } \\
\text { TDN }\end{array}$ & $\begin{array}{c}\text { Post-calving } \\
\text { TDN } \\
\text { intake/day }\end{array}$ & $\begin{array}{c}\text { Proportion } \\
\text { intake/day } \\
(\mathrm{kg})\end{array}$ & $\begin{array}{c}\text { Des cows } \\
\text { diagnosed } \\
\text { pregnant } \\
(\%)\end{array}$ \\
\hline 4.1 & 7.3 & High-High & 95 \\
4.1 & 3.6 & High-Low & 77 \\
2.0 & 7.3 & Low-High & 95 \\
2.0 & 3.6 & Low-Low & 20 \\
\hline
\end{tabular}

'Presented by Wiltbank and others (1962).

${ }^{2}$ Approximates the requirements for mature cows given by the National Research Council.

be made from the results of this paper is that there is sharp distinction between physical and economic efficiency. As shown in Table 4, 95\% calf crops are achieved with the high-high and the low-high feeding regimens. However, because of the higher feed cost involved, the high-high feeding rate yields a net income less than that of the low-high feeding rate. In terms of net income, the high-low feeding rate would be preferable to the high-high feeding rate since net income is higher even though the calf crop is only $77 \%$. Thus, while a higher calf crop is normally preferable to a lower calf crop, producers should consider the added cost and return of achieving a higher calf crop. The higher calf crop is economically feasible only if the added returns are at least equal to the added cost.

At the low-low energy levels, calf crop would be at the $20 \%$ level. At this level of calf crop, the number of cows raised would decrease

Table 4. Effect of alternative energy levels on net revenues.

\begin{tabular}{lccc}
\hline \hline Designation & Calf Crop (\%) & $\begin{array}{c}\text { Cows Raised } \\
\text { (Head) }\end{array}$ & $\begin{array}{c}\text { Net Revenue } \\
\mathbf{( \$ )}\end{array}$ \\
\hline High-High & 95 & 178 & 21,627 \\
High-Low & 77 & 198 & 25,389 \\
Low-High & 95 & 225 & 25,767 \\
Low-Low & 20 & 0 & 0 \\
\hline
\end{tabular}


to 0 and net income would also decline to $0 .{ }^{1}$ Practically, at this level of calf crop, it would not be economically feasible to remain in business. Again, the marginal principle prevails. The added return associated with remaining in the cow business at a $20 \%$ calf crop does not justify the added cost. In this instance, added returns and added costs are viewed in terms of the total operation; and, if the rancher were to remain in business (with the same cow herd size as the high-low feeding regimen, 198 head), total cost of operation (variable cost) is $\$ 14,699$. Total returns are $\$ 10,528$ (including culled cow and bull sales). Clearly, the rancher would be better off not producing any calves since this would result in a return of $-\$ 4,171$.

The results of this study are not conclusive in the sense of recommending a specific calf crop percentage towards which all producers should strive. Feed availabilities and feed costs during the pre-calving and post-calving periods will largely determine the economically "optimal" calf crop. The only conclusive point to be made is that a higher calf crop is not necessarily better in an economic sense than a lower calf crop. The decision of which calf crop is better can only be weighed in specific situations when added costs are compared to added returns.

The authors recognize that there a re a number of limitations to this analysis. For example, calving percentage was considered the major variable in the analysis. Yet, the authors are aware that other factors would also vary with energy intake and influence net income such as selling weight, death loss, and early or late conception. Further, the data on calf crops as related to alternative feeding regimens are limited in relating to only four levels. The authors would have preferred data that included more calf crop levels as they relate to feed intake under range conditions. Removal of these limitations are suggested for future research on a problem critical to the Western range cattle industry.

'Recall that net income includes only operating or "variable" costs. If fixed costs were part of the net income definition, the figures reported in Table 5 would be smaller in magnitude. And, for the $20 \%$ calf crop (and possibly for other calf crop percentages), net income would be negative.

\section{Literature Cited}

Bartlett, B.T., G.R. Evans, and R.E. Bement. 1974. A serial optimization model for ranch management. J. Range Manage. 27:233-239.

Beneke, R.R., and R. Winterboer. 1973. Linear programming applications to agriculture. lowa State Univ. Press, Ames.

Bottoms, K.E., and E.T. Bartlett. 1975. Resource allocation through goal programming. J. Range Manage. 28:442-447.

Ching, C.T.K., R.L. Christensen, and T.J. Ulrich. 1977. A linear programming model of Nevada ranch enterprises. Nevada Agr. Exp. Sta. Bull. T22.

Connor, J.M., V.R. Bohman, A.L. Lesperance, and F.E. Kinsinger. 1963. Nutritive evaluation of summer range forage with cattle. J. Animal Sci. 22:961-969.

D'Aquino, Sandy A. 1974. A case study for optimal allocation of range resources. J. Range Manage. 27:228-233.

Dunn, T.G., G.E. Ingalls, D.R. Zimmerman, and J.N. Wiltbank. 1969. Reproductive performance of 2-year-old Hereford and Angus heifers as influenced by pre- and post-calving energy intake. J. Animal Sci. 29:719-726.

Hewlett, D.B., and J.P. Workman. 1978. An economic analysis of retention of yearlings on range and potential effects on beef production. J. Range Manage. 31:125-128.

Leistritz, L.F., and N.J. Qualey. 1975. Economics of range management alternatives in Southwestern North Dakota. J. Range Manage. 28:349352.

Mitchell, B., and J.R. Garrett. 1977. Characteristics of the range cattle industry 1972 region 111 northeastern Nevada. Nevada Agr. Exp. Sta. Bull. B42.

Rogers, Leroy F., and William C. Helming. 1967. Characteristics of the range cattle industry in Nevada, region III, northeastern Nevada. Nev. Agr. Bull.

U.S. Department of Agriculture. 1978. Agricultural Prices. ESCS, Washington, D.C.

Wiltbank, J.N., W.W. Rowden, J.E. Ingalls, K.E. Gregory, and R.M. Koch. 1962. Effect of energy level on reproductive phenomena of mature Hereford cows. J. Anim. Sci. 21:219-225.

Wiltbank, J.N., W.W. Roden, J.E. Ingalls, and D.R. Zimmerman. 1964. Influence of post-partum energy level on reproductive performance Hereford cows restricted in energy intake prior to calving. J. Anim. Sci. 23:1049-1053.

Woodworth, Bruce M. 1973. Optimizing the calf mix on range lands with linear programming. J. Range Manage. 26:175-178. 